CANDÉO, M; CANTERI, MHG; MACEDO, DC; KUBASKI, ET; TEBCHERANI, SM. 2020. Postharvest durability of tomatoes with PVA covering. Horticultura Brasileira, 38: 160-165. DOI - http://doi.org/10.1590/S0102-053620200208

\title{
Postharvest durability of tomatoes with PVA covering
}

\author{
Manuella Candéo ${ }^{1} \mathbb{D}$; Maria Helene G Canteri ${ }^{1} \mathbb{D}$; Dayana Carla de Macedo ${ }^{1 ; 2} \mathbb{D}$; Evaldo T Kubaski ${ }^{3} \mathbb{D}$; \\ Sergio M Tebcherani ${ }^{1}$ (D)
}

${ }^{1}$ Universidade Tecnológica Federal do Paraná (UTFPR), Ponta Grossa-PR, Brasil; sergio@nanoita.com.br; ${ }^{2}$ Universidade Estadual do Centro-Oeste (UNICENTRO), Irati-PR, Brasil; dayanacarlademacedo@gmail.com; ${ }^{3}$ Universidade Estadual de Ponta Grossa (UEPG), Ponta Grossa-PR, Brasil; evaldotk@outlook.com

\begin{abstract}
Plastic packaging from petroleum derives used in the food industry represents serious environmental problems. Alternative solutions to these problems consist of the development of biodegradable packaging, such as films and edible coatings including the polyvinyl alcohol (PVA). In this research we evaluated the effect of the PVA application by two different techniques aiming to increase shelf life of ripe tomatoes, cultivar Carmen. The methodology of this study consisted in covering tomatoes with a PVA solution and also with PVA impregnated tracing paper. The different fruit lots were kept in polystyrene trays for 19 days on a laboratory bench at a controlled temperature of $25 \pm 3^{\circ} \mathrm{C}$. The fruit analyzes were compared to the control fruits without any treatment, being evaluated firmness, $\mathrm{pH}$, titratable total acidity, mass loss, total soluble solids content, water activity and color determination of fruit surface. Among the different treatments, the PVA coating applied directly to the fruits contributed to control the firmness and the mass loss, as well as this treatment influenced the total soluble solids content, the luminosity and the red color of fruits with statistical difference compared to the control and covered with tracing paper (with or without PVA). The PVA coating solution applied directly on the fruits contributed to maintain the postharvest quality of the ripe tomatoes.
\end{abstract}

Keywords: Lycopersicon esculentum, biodegradable packaging, shelf life, perishability.

\section{RESUMO}

Durabilidade pós-colheita de tomates embalados em PVA

As embalagens plásticas de derivados do petróleo utilizadas na indústria alimentícia representam sérios problemas ambientais. Soluções alternativas para esse tipo de problema consistem no desenvolvimento de embalagens biodegradáveis, tais como filmes e coberturas comestíveis, como o álcool polivinílico (PVA). Neste trabalho avaliou-se o efeito da aplicação de PVA por duas diferentes técnicas visando aumentar a vida de prateleira de tomates maduros da cultivar Carmen. A metodologia deste trabalho consistiu no recobrimento do fruto com solução de PVA e também com papel vegetal impregnado com PVA. Os diferentes lotes de frutos permaneceram em bandejas de isopor durante 19 dias em bancada de laboratório em temperatura controlada de $25 \pm 3^{\circ} \mathrm{C}$. As análises dos frutos foram comparativas aos frutos controle sem qualquer tipo de tratamento, sendo avaliados a firmeza do fruto, $\mathrm{pH}$, acidez total titulável, perda de massa, teor de sólidos solúveis, atividade de água e a cor da superfície dos frutos. Dentre os diversos tratamentos, o revestimento de PVA aplicado diretamente nos frutos contribuiu para controlar a firmeza e perda de massa, bem como o teor de sólidos solúveis totais, luminosidade e cor vermelha dos frutos, com diferença estatística em relação ao controle e frutos cobertos com papel (com ou sem PVA). Assim, foi possível observar que a solução de revestimento de PVA aplicada diretamente nos frutos contribuiu para a manutenção da qualidade pós-colheita dos tomates maduros.

Palavras-chave: Lycopersicon esculentum, embalagem biodegradável, vida de prateleira, perecibilidade.

\section{Received on April 15, 2019; Accepted on March 31, 2020}

$\mathrm{T}$ omato is a worldwide marketed fruit, consumed in natura, in the form of salads, sauces or condiments, as pickles. Due to their high perishability and water activity content, many tomatoes are lost during the commercialization process (Panozzo et al., 2013).

Significant losses are observed during and after harvest, possibly caused by mechanical damages, through inadequate storage and transport conditions, as well as during sale display that may favor the fruits contamination by fungi and bacteria (Oliveira et al., 2015).

Films and coatings can be applied to fruits and vegetables to reduce the loss of moisture, lipids and aromas, the exchange between oxygen and carbon dioxide, among others, since they act as semipermeable barriers (Chiumarelli \& Ferreira, 2006). Furthermore, it is possible to incorporate compounds such as antioxidants, antimicrobials and aromatics to the films and coatings, at the same time as these films confer the property of improving the mechanical integrity and handling characteristics (Evangelista et al., 2014).

Natural biodegradable coatings were prepared with polysaccharides, proteins, lipids, or even a blend of these compounds (Dhall, 2013; Arnon et al., 2014). Biodegradable coatings are used to extend shelf life and to make fruits more attractive (Das et al., 2013). 
The PVA is a water-soluble synthetic polymer, thermoplastic, tasteless and odorless being synthesized by vinyl acetate polymerization.

The reversible transformation between polyvinyl alcohol and vinyl polyacetate was studied by Staudinger in 1961 through esterification and saponification reactions (Marten, 1985).

PVA is a polymer obtained by polymerizing vinyl acetate, followed by the hydrolysis reaction of polyvinyl acetate in polyvinyl alcohol. This polymer has excellent properties such as transparency, nontoxicity and biodegradability, as well as soft consistency when in membrane form.

Studies and the development of biodegradable packaging to increase shelf life of tomatoes are expanding while there is a shortage of these products on the market. Thus, the objective of this study was to evaluate the effect of the application of two different PVA-based packaging techniques in order to extend shelf life of ripe tomatoes, cultivar Carmen.

\section{MATERIAL AND METHODS}

During the 2018 harvest, mature tomatoes were obtained from commercial producers in Ponta Grossa (Parana State, Brazil). The mature and undamaged fruits were selected to have a homogenous raw material; green or senescent fruits were discarded. One sample of ripe tomatoes was used as standard for visual comparison red colored and uniform size (approximately 40 to $50 \mathrm{~mm}$ diameter).

The tomatoes were sanitized with $150 \mathrm{ppm}$ sodium hypochlorite (Synth) solution at $4^{\circ} \mathrm{C}\left( \pm 2^{\circ} \mathrm{C}\right)$ temperature during 20 minutes, rinsed in tap water and dried naturally.

Two batches of unpacked fruits (paper and paper + PVA only) and two unpackaged fruits (control, PVA solution coating) were analyzed, with 45 samples for each, totaling 180 tomatoes.

The solution of PVA-based edible coating (PVA solution) was prepared by mixing 8 grams of polyvinyl alcohol (Neon), 12 grams of ethylene glycol (Synth) and 80 grams of water, under mechanical stirring on a heating plate at $70^{\circ} \mathrm{C}$, until complete dissolution.

This PVA solution was applied over the length of the tracing paper on both sides with the aid of a thin bristle brush. This paper (PVA paper) was dried at room laboratory temperature for 36 hours.

To study and characterization, tomatoes were prepared according to four different assays, after sanitization process: a) control (tomatoes without any treatment); b) PVA solution coating (tomato coated with PVA solution. The fruits were immersed in the PVA solution for 10 minutes, then removed and kept in air until drying); c) PVA paper (each fruit was individually wrapped with tracing paper impregnated with PVA solution); d) without PVA paper (each fruit was individually wrapped with tracing paper).

The tomatoes were placed on polystyrene trays on laboratory benches in controlled temperature $\left(25^{\circ} \mathrm{C} \pm 3^{\circ} \mathrm{C}\right)$ for 19 days, with no contact between fruits.

Physicochemical analyzes were performed on fruits after 24 hours (in order to guarantee the effect of each package) and in triplicate for 11 consecutive days thereafter were evaluated every 72 hours until the $19^{\text {th }}$ day. The results are expressed as the mean of those values with the standard deviation to each parameter.

Due to the fruit senescence process, only those with good physicochemical condition continued to be evaluated. The remainder was discarded due to signs of rot such as differentiated odor, appearance of injuries, softening of the peel, and release of liquids.

The obtained data were statistically evaluated through graphs using criteria of comparison of results. A completely randomized design was used because the conditions of the experiment were carried out in a completely controlled manner. For comparative purposes, the chemical results were submitted to analysis of variance (ANOVA) and the means compared using Tukey's test at a significance level of $5 \%$ by SASMAgri software Version 8.2 (Canteri et al., 2001).

The analyzes performed were firmness, $\mathrm{pH}$, titratable total acidity, mass loss, total soluble solids content, water activity and color of fruit surface.

Fruit firmness analysis was carried out using a texturometer (CT3 Texture Analyzer) with a tip of 10 grams, deformation $2 \mathrm{~m} / \mathrm{m}$ and a speed of 10 $\mathrm{mh} \mathrm{s}^{-1}$. Directly in the juice extracted from the fruit, $\mathrm{pH}$ was evaluated in a $\mathrm{pH}$ meter (Q400MT Quimis), according to the standard methodology (IAL, 2008) and titratable acidity (total acidity), expressed in percent of citric acid was determined by titrimetric method (IAL, 2008). Mass loss was calculated according to equation 1 .

$$
\mathrm{P}=\frac{\mathrm{M}_{\mathrm{to}}-\mathrm{M}_{\mathrm{tf}}}{\mathrm{M}_{\mathrm{to}}} \times 100 \quad \text { Equation } 1
$$

Where $\mathrm{P}$ is the percentage of mass loss $(\%), \mathrm{M}$ is the mass of the fruit (g) and the time is represented by the index $\mathrm{t}$.

The total soluble solids content was determined in a benchtop refractometer laboratory (ABBE Refractometer) with a refractive range of 1,300-1,720 $\mathrm{nD}$ and from 0 to $95 \%$ Brix with correction for temperature, in accordance with the literature-based methodology (AOAC, 2000).

The water activity was measured in an AquaLab-Series-4TE on a sample with an area of $1 \mathrm{~cm}$ in diameter approximately.

The evaluation of the instrumental color was carried out directly in the fruit surface, with a colorimeter (CR-410 Chroma Minolta Meter). CIE L* a* b* color-space coordinates, as well as $\mathrm{C}^{*}$ index was evaluated. $\mathrm{L}^{*}$ value represents luminosity of color stimulation, ranging from zero (black) to 100 (white), a* ranging from green $(-60)$ to red $(+60), b^{*}$ ranging from blue $(-60)$ to yellow $(+60)$ and $\mathrm{C}^{*}$ representing chroma relating to color intensity (Buckley \& Giorgianni, 2015). This equipment was programmed in order to calculate the mean of ten measurements on each fruit, performed in triplicate.

To verify the color variation in relation to reference tomatoes, the value of DE was determined in equation 2, which is the distance between two colors using the space $\mathrm{L}^{*} \mathrm{a} * \mathrm{~b} *$ to define the values of each color. 
$\Delta \mathrm{E}=\left[(\Delta \mathrm{L})^{2}+\left(\Delta \mathrm{a}^{2}\right)+\Delta \mathrm{b}^{2}\right]^{1 / 2} \quad$ Equation 2

L, $a$ and $b$ are the CIELab coordinates, index 1 refers to the values of reference tomatoes and index 2 of coated tomatoes, whether with PVA, paper with PVA or with tracing paper. For analysis, the closer the value of $\mathrm{DE}$ is to 0 , the smaller the difference in colors will be and the closer to the selected pattern.

\section{RESULTS AND DISCUSSION}

During the experiments, variation in firmness was observed in the fruits (Figure 1). There was no statistically significant difference between tomato firmness during assay time for any of the treatments until the eleventh day, probably due to the values measured by used methodology presented a relatively higher standard deviation compared to the other measurements. The calculated $F$ was 0.43 for the control, 1.92 for the paper PVA free, 0.39 for PVA paper and 1.91 for PVA solution coating, being all values greater than critical $F$ of 4.06 (significance level of 5\%). By Tukey's test, the treatment with PVA solution coating showed significant differences from the other treatments or control, with calculated $\mathrm{F}=5.47$ higher than the critical $\mathrm{F}=2.81$ (significance level of $5 \%$ ) according to ANOVA.

This is also confirmed by the higher firmness values on day 11 compared to other treatments, confirming that PVA coverage was effective for maintaining fruit firmness for a longer time.

In the senescence period (after $11^{\text {th }}$ day of assay), all samples lost the firmness of the pulp during ripening (Figure 1). However, we need emphasize that these changes are unique to each fruit, even if harvested at the same time from the same plant with similar appearance.

Changes in pulp firmness are associated with the transformation during the ripening of the fleshy fruits, directly affecting their quality and shelf life due to the direct relation to the chemical components bound to the cell wall (Toivonen \& Brummell, 2008).

Tomatoes coated with PVA still did not have yet signs of rot after the $13^{\text {th }}$ day (Figure 1), whereas the other treatments had an evident deterioration, preventing the analysis of the control treatment. On the $19^{\text {th }}$ day of the experiment (Figure 1), tomatoes with PVA presented a slight deformation degree, while maintaining a texture for food consumption.

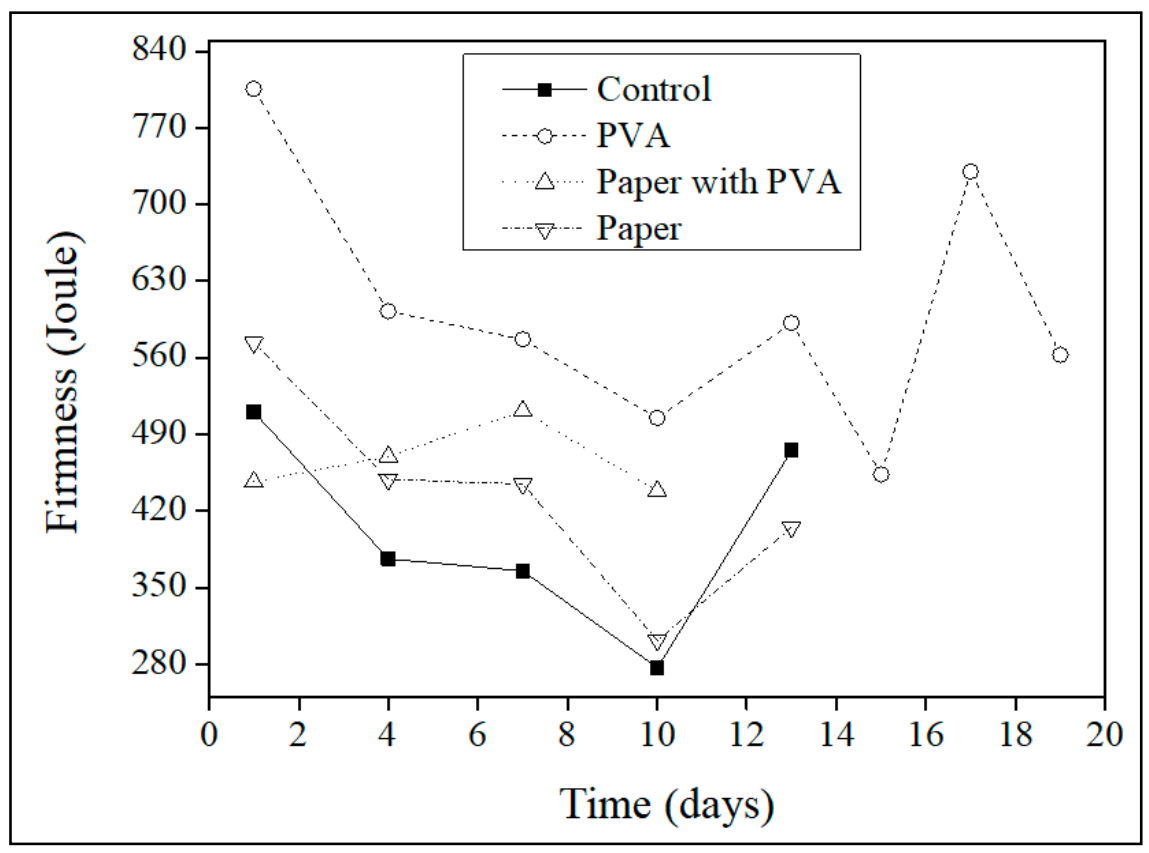

Figure 1. Firmness of control and different tomato treatments, determined through texturometer during the period of 19 days. Ponta Grossa, UTFPR, 2018.
The mass loss showed a linear behavior depending on storage time in all treatments (Figure 2). The results obtained are consistent with the literature (Sammi \& Masud, 2009; Mwendwa et al., 2016; Munaretto et al., 2018), describing that the fruit mass decreases over time according to ripening.

There was statistically significant difference between the initial and final tomato mass during assay time between all treatments until the $11^{\text {th }}$ day, with a constant decrease. The calculated F was 23.25 for control, 26.39 for paper PVA free, 31.23 for PVA paper and 28.53 for PVA solution coating. All values are greater than critical $\mathrm{F}$ at $5 \%$ significance (2,81).

Regarding the different treatments, PVA coating solution showed a significant difference from paper PVA free, according to Tukey's test. The PVA paper and the control treatment remained in the same group, with a calculated $F$ of 3.77 higher than the critical $\mathrm{F}$ of 2.90 (significance level of 5\%) according to ANOVA.

There was a lower average mass loss in the PVA coverage treatment compared to the other treatments, confirming that PVA coverage decreased gas exchange associated with fruit respiration. The tomatoes with PVA solution coating had a similar mass loss up to the $17^{\text {th }}$ day of the experiment, but with better linearity (Figure 2). However, the PVA on the surface has not influenced the tomato respiration and perspiration (Chiumarelli \& Ferreira, 2006). Tomatoes covered with paper (PVA and PVA free) maintained linearity only until the $13^{\text {th }}$ day.

Respiration is considered the major cause of mass decrease of fruits and vegetables. This water loss is related to the difference in water vapor pressure between the surrounding atmosphere and the surface of the fruit (Gharezi et al., 2012) as well as also to perspiration, when $\mathrm{CO}_{2}$ is eliminated into the atmosphere. When water loss is high, there are possible changes in the appearance and acceptability of the product as food (Chitarra \& Chitarra, 2005).

The amount of total soluble solids did not show variation according to 
the time intervals, despite the intrinsic differences between fruits of the same cultivar (Figure 3). Total soluble solids play an important role in the quality of the fruit, since they influence the physical, chemical and biological properties of fruits. The different metabolic processes are associated to the progress of ripening (Sammi \& Masud, 2009). Nevertheless, one of the explanations may be due to the dissociation of some molecules and structural enzymes into soluble compounds that directly influence the solubility because very mature fruits show higher values of soluble solids (Sammi \& Masud, 2009).

Due to the fact that the tomatoes were ripe at the beginning of the experiment, there were oscillations in the results of degrees Brix, with statistically different results as a function of time, but with diversity of behavior, without linearity in the increase or reduction (Figure 3). There was a statistically significant difference between soluble solids content and different treatments, with a calculated $F$ of 5.76 higher than the critical F of 2.81, up to the $11^{\text {th }}$ day. PVA solution coating tomatoes (group a) were statistically different from paper PVA free tomatoes (group b). Tomatoes with PVA paper (group ab) and control treatment (group ab) were in the same group according to Tukey's test.

The organic acids and sugars found in fruits are a quality indicator and can serve as a reference for the ripening stage (Chitarra \& Chitarra, 2005). The volatility of some acids may contribute to the characteristic aroma of fruits (Munaretto et al., 2018). The concentration of organic acids generally decreases in relation to the substrate in respiration or during the conversion process to sugars (Chiumarelli \& Ferreira, 2006). The changes occur according to the storage, being important in the organoleptic characteristics (Chitarra \& Chitarra, 2005).

There was a statistically significant difference between titratable total acidity versus time. For control and paper PVA free, $\mathrm{F}_{\text {calc }}=7.14$ higher than the $F_{\text {critical }}$ (4.06), and at the end of the test time the acidity was lower. However, there was no statistically significant difference during the test for PVA paper $\left(\mathrm{F}_{\text {calc }}=1.24\right)$ and PVA coating solution $\left(\mathrm{F}_{\text {calc }}^{\text {calc }}=0.87\right)$. Regarding treatments, only paper PVA free was statistically different from the others $\left(\mathrm{F}_{\text {calc }}=18.68\right.$ higher than $\left.\mathrm{F}_{\text {critical }}=2.81\right)$.

During the essays period, there was a small variation in the $\mathrm{pH}$ range, justified because all tomatoes were ripe since the beginning of the experiment. These

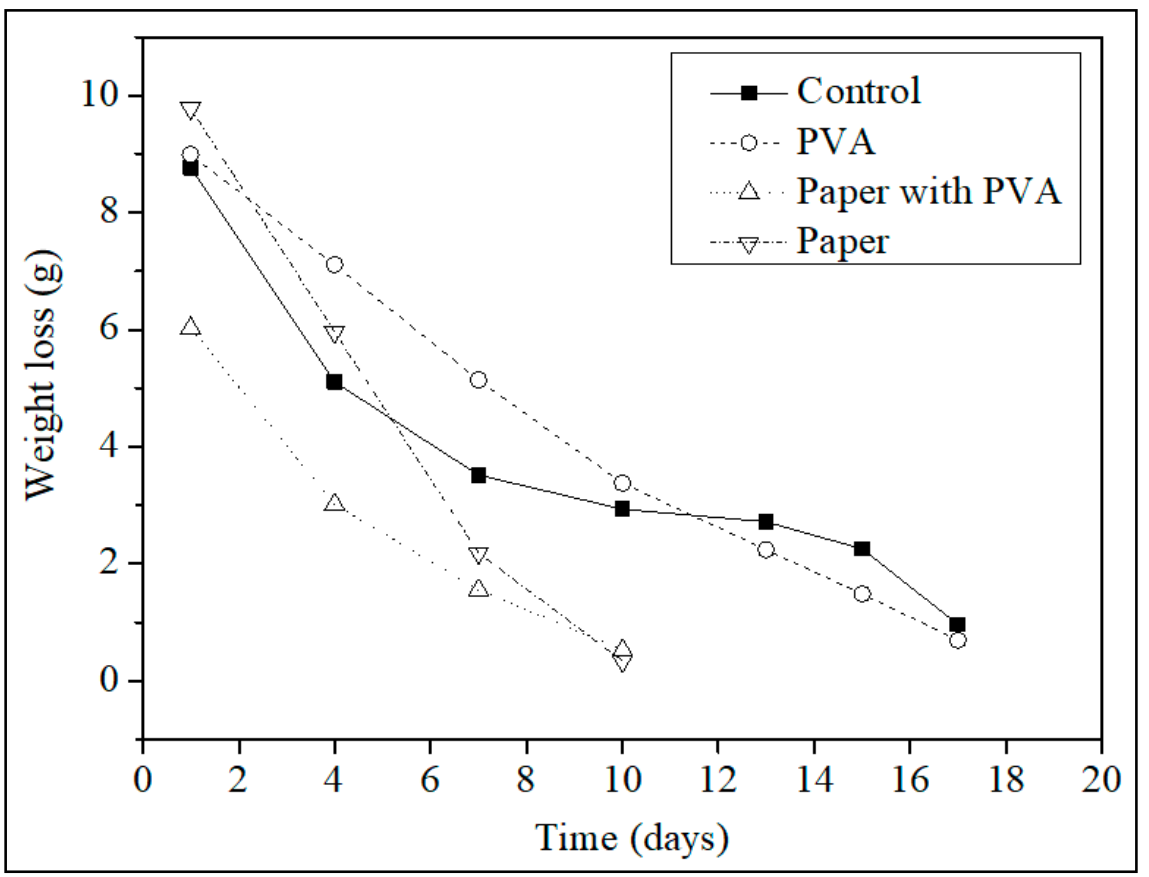

Figure 2. Mass of control and different tomato treatments obtained during the period of 17 days. Ponta Grossa, UTFPR, 2018. measured values were similar to other authors (Cliff et al., 2009), close to the range of 4.00 and 4.50 .

There was no statistically significant difference between $\mathrm{pH}$ during essay time nor between treatments. Regarding the time, for control treatment the $\mathrm{F}_{\text {calc }}$ was 0.30 , for paper PVA free $\mathrm{F}_{\text {calc }}=0,11$, for PVA paper $\mathrm{F}_{\text {calc }}=0,52$ and for PVA solution coating $\mathrm{F}_{\text {calc }}=1,58$. When the different treatments were compared, $\mathrm{F}_{\text {calc }}=0,50$ was lower than $\mathrm{F}_{\text {critical }}=2,06$.

Water activity (Aw) was not statistically influenced by the treatments or ripening time. For all essays, the water activity (Aw) remained constant, with total average of 0.9726 .

The control tomatoes and paper wrapped tomatoes resisted without apparent injuries until the $13^{\text {th }}$ day of the experiment, while the tomatoes covered with PVA paper resisted only until the $10^{\text {th }}$ day of the experiment. However, PVA coated tomatoes remained constant until the $19^{\text {th }}$ day of the experiment. This may correspond to a great advantage for the consumer market, as the appearance is responsible for choosing tomatoes in supermarket gondolas.

There was no intense color oscillation during the whole storage period, either between tomatoes, or between different treatments. There was no statistically significant difference between luminosity (L*) versus time. For all treatments $\mathrm{F}_{\text {calc }}$ was lower than $\mathrm{F}_{\text {critical }}$ (4.06). The values were $\mathrm{F}_{\text {calc }}=1.89$ for control treatment, 1.27 for paper PVA free, 1.01 for PVA paper and 0.05 for PVA coating solution. However, there was statistically significant difference comparing the different treatments, with $\mathrm{F}_{\text {calc }}=4.15$ higher that $\mathrm{F}_{\text {critical }} 2.83$. PVA solution coating tomatoes (group b) were statistically different from control (group b). Tomatoes with PVA paper (group ab) and PVA free paper (group ab) remained in the same group according to Tukey's test. According these results, tomatoes covered with PVA coating solution were darker than other treatments, which may be a plus point in consumer choice specifically for tomatoes.

Also, there was no statistically significant difference between parameter $\mathrm{a}^{*}$ ranging from green $(-60)$ to red $(+60)$, 


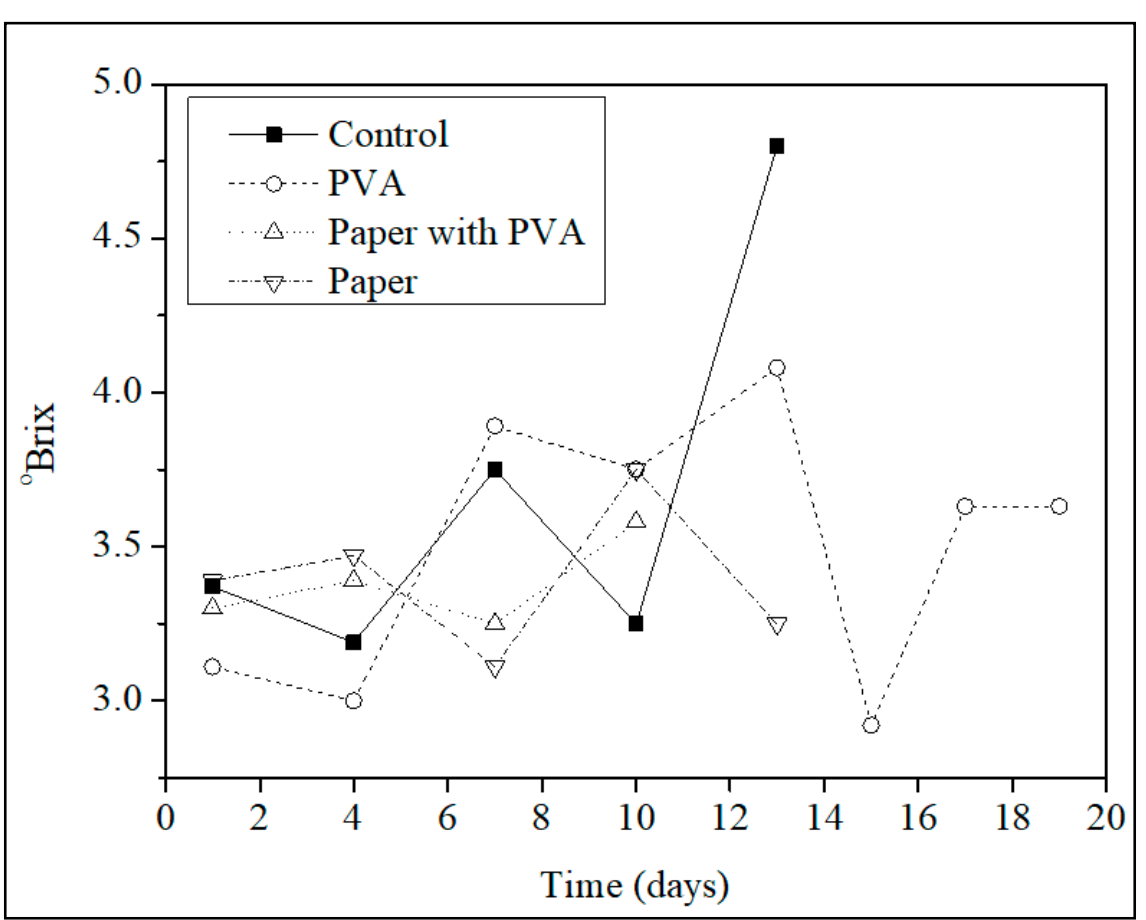

Figure 3. Total soluble solids content of control and different tomato treatments obtained during the period of 19 days. Ponta Grossa, UTFPR, 2018.

and the color variation (DE) during the time of the assays, where $\mathrm{F}_{\text {calc }}$ was lower than $\mathrm{F}_{\text {critical }}$ (4.06). Nevertheless, the comparison between treatments showed statistically significant difference for $\mathrm{a}^{*}$ $\left(\mathrm{F}_{\text {calc }}=4.61>\mathrm{F}_{\text {critical }}=2.83\right)$. According to Tukey's test, PVA solution coating tomatoes and PVA paper (group a) were statistically different from control (group b); paper PVA free remained in the group ab. According these results, tomatoes covered with PVA coating solution and PVA paper showed a more intense red color than the other treatments (without PVA application). This can also be considered a positive factor in consumer choice of product.

Considering the parameter $b^{*}$ for color, ranging from blue (-60) to yellow $(+60)$, there was statistically significant difference versus time only for treatment PVA coating, resulting $\mathrm{F}_{\text {calc }}=48.92>$ $\mathrm{F}_{\text {critical }}=4.06$ ). In this case, around the $11^{\text {th }}$ day of assay, tomatoes with PVA coating showed color less yellow than other treatments. For the $\mathrm{b}^{*}$ color and the color variation $(\mathrm{DE})$, there was no statistically significant difference between treatments.

When coated tomatoes were compared to control tomatoes, color variations (DE) were found to be 6.3 for PVA-coated tomatoes, and 4.2 both for tomatoes wrapped with tracing paper (PVA or PVA free). The results show that the tomatoes did not undergo color changes due to the coatings. The difference was $3.6 \%$ for PVAcoated tomatoes and $2.4 \%$ for tomatoes wrapped with different papers.

However, the color difference between the coated tomatoes did not show any significant variation $(5 \%)$ during the essay time, probably because the tomatoes selected had red color since the beginning.

The tests with PVA as a coating for tomato fruits of the cultivar Carmen at room temperature evidenced that this edible and biodegradable substance can contribute to the quality maintenance of red and ripe tomatoes regarding the characteristics of fresh mass, firmness, titratable total acidity, total soluble solids, $\mathrm{pH}$, color and water activity up to the period of 19 days. This time exceeded the maintenance period of control tomatoes, which was only 13 days.

On the other hand, the use of tracing paper, with PVA or PVA free, accelerated the degradation of the tomatoes to the interval of 11 days. This factor could favor more efficiency in the juices and extracts tomato processing.

The determination of the color through the CIELab coordinates showed that the color variation of the tomatoes was very low, during test time or compared with the reference tomatoes.

Among three different treatments to increase the shelf life of Carmen tomatoes, fruit surface coating with a PVA coating solution was most effective in delaying the changes inherent to modifications in ripe and ready-to-eat fruits.

Fruit firmness, weight loss, lightness and red color were positively influenced, with statistical differences compared to paper-coated tomatoes (PVAimpregnated or PVA-free) and tomatoes without postharvest treatment.

The PVA coating solution treatment can be easily applied by producers, increasing the exposure time of the product for sale to the consumer.

\section{REFERENCES}

AOAC, 2000. Official methods of analysis of the Association of Official Analytical Chemists. First action.

ARNON, H; ZAITSEV, Y; PORAT, R; POVERENOV, E. 2014. Effects of carboxymethyl cellulose and chitosan bilayer edible coating on postharvest quality of citrus fruit. Postharvest Biology and Technology 87: 21-26.

BUCKLEY, RR; GIORGIANNI, EJ. 2015. Encyclopedia of Color Science and Technology. Berlin Heidelberg: Springer. p1-9.

CANTERI, MG; ALTHAUS, RA; VIRGENS FILHO, JS; GIGLIOTI, EA; GODOY, CV. 2001. SASM-Agri - Sistema para análise e separação de médias em experimentos agrícolas pelos métodos Scott-Knott, Tukey e Duncan. Revista Brasileira de Agrocomputação 1: 18-24.

CHITARRA, MIF; CHITARRA, AB. 2005. Póscolheita de frutas e hortaliça: Fisiologia e Manuseio 2.ed. Lavras: UFLA. 783p.

CHIUMARELLI, M; FERREIRA, MD. 2006. Qualidade pós-colheita de tomates 'Débora' com utilização de diferentes coberturas comestíveis e temperaturas de armazenamento. Horticultura Brasileira 24: 381-385.

CLIFF, M; LOK, S; LU, C; TOIVONEN, PMA. 2009. Effect of 1-methylcyclopropene on the sensory, visual, and analytical quality of greenhouse tomatoes. Postharvest Biology and Technology 53: 11-15.

DAS, DK; DUTTA, H; MAHANTA, CL. 2013. Development of a rice starch-based 
coating with antioxidant and microbe-barrier properties and study of its effect on tomatoes stored at room temperature. LWT - Food Science and Technology 50: 272-278.

DHALL, RK. 2013. Advances in edible coatings for fresh fruits and vegetables: a review. Critical Reviews in Food Science and Nutrition 53: 435-50.

EVANGELISTA, RM; MENDES, ASG; CORRÊA, CV; CARDOSO, AII. 2014. Uso de películas comestíveis e gelatina na conservação de frutos de mini tomate orgânico 'sweetgrape'. Revista Iberoamericana de Tecnología Postcosecha 15: 168-176.

GHAREZI, M; JOSHI, N; SADEGHIAN, E. 2012. Effect of postharvest treatment on stored cherry tomatoes. Journal of Nutrition \& Food Sciences 2: 157.

IAL-Instituto Adolfo Lutz. 2008. Métodos físicoquímicos para análise de alimentos. São
Paulo: Instituto Adolfo Lutz. 1020p.

MARTEN, FL. 1985. "Vinyl alcohol polymers", in: MARK, HF; BIKALES, NM; OVERBERGER, CG; MENGES, G (eds). Encyclopedia of Polymer Science and Engineering. New York: John-Wiley. vol. 17.

MUNARETTO, LM; BOTELHO, RV; RESENDE, JTV; SCHWARZ, K; SATO, AJ. 2018. Productivity and quality of organic strawberries pre-harvest treated with silicon. Horticultura Brasileira 36: 040-046.

MWENDWA, R; OWINO, OW; AMBUKO, J; WAWIRE, M; NENGUWO N. 2016. Characterization of postharvest physiology attributes of six commercially grown tomato varieties in Kenya. African Journal of Food, Agriculture, Nutrition and Development 16: 10613-10631.

OLIVEIRA, CM; CONEGLIAN, RCC; CARMO, MGF. 2015. Conservação pós-colheita de tomate cereja revestidos com película de fécula de mandioca. Horticultura Brasileira 33: 471-479.

PANOZZO, A; LEMMENS, L; VAN LOEY, A; MANZOCCO, L; NICOLI, MC; HENDRICKX, M. 2013. Microstructure and bioaccessibility of different carotenoid species as affected by high pressure homogenization: a case study on differently coloured tomatoes. Food Chemistry 141: 4094-100.

SAMMI, S; MASUD, T. 2009. Effect of different packaging systems on the quality of tomato (Lycopersicon esculentum var. Rio Grande) fruits during storage. Journal of Food Science \& Technology 44: 918-926.

TOIVONEN, PMA; BRUMMELL, DA. 2008. Biochemical bases of appearance and texture changes in fresh-cut fruit and vegetables. Postharvest Biology and Technology 48: 1-14. 